\title{
Effects of light-emitting diodes on muscle fatigue and exercise tolerance in patients with COPD: study protocol for a randomized controlled trial
}

\author{
Eduardo Foschini Miranda ${ }^{1}$, Ernesto Cesar Pinto Leal-Junior ${ }^{1,2}$, Paulo Henrique Marchetti ${ }^{3}$ and Simone Dal Corso ${ }^{1,4^{*}}$
}

\begin{abstract}
Background: Light-emitting diodes (LED) have been used to minimize muscle fatigue in athletes and healthy subjects. Patients with chronic obstructive pulmonary disease (COPD) are susceptible to early muscle fatigue.

Objective: The objective of this study is to investigate the acute effects of LED on muscle function, exercise capacity and cardiorespiratory responses during isometric and dynamic exercise in patients with COPD.

Methods: This study will assess 30 patients with moderate to severe obstruction (forced expiratory volume-one second,FEV ${ }_{1} \leq 70 \%$ predicted). Isometric and dynamic protocols will be conducted in two visits each, for a total of four visits a week apart. First, venous blood will be taken from the patients. The isometric protocol will start with the determination of the maximum voluntary isometric contraction (MIVC) to determine the workload (60\% of MIVC) for the isometric endurance test (IET). Patients will be randomized to receive either the placebo or LED application (each point will be irradiated for $30 \mathrm{~s}$ and the energy received at each point will be $41.7 \mathrm{~J}$ ). Immediately after finishing this procedure, the patients will carry out the IET until the limit of tolerance or until a $20 \%$ fall of strength is observed. After the test, another blood draw will be taken. In another visit (one week later), the same order of procedures will be performed, except with the opposite (LED or placebo). For the dynamic endurance test (DET), the same procedures described above will be followed, except with $75 \%$ of the maximal workload obtained from the incremental cycle ergometer test used instead of the IET. The electromyography will be recorded during the isometric and dynamic protocols. Differences in muscle function, exercise capacity and cardiorespiratory responses between the LED and placebo applications will be analyzed. The therapeutic effects of LED could minimize muscle fatigue in patients with COPD by increasing exercise tolerance.
\end{abstract}

Trial registration: Trial registration number: NCT01448564

Keywords: COPD, Phototherapy, LED, Muscle fatigue

\section{Background}

Chronic obstructive pulmonary disease (COPD) primarily affects the lungs, but it is a systemic disease with several extra-pulmonary manifestations, most notably peripheral muscle dysfunction [1].

Skeletal muscle dysfunction in patients with COPD is characterized by a reduction of muscle strength [2] and endurance [3]. There is also a redistribution of muscle

\footnotetext{
* Correspondence: simonedc@uninove.br

'Post Graduate Program in Rehabilitation Sciences, Nove de Julho University, São Paulo, Brazil

${ }^{4}$ Rua Vergueiro 235/249 2 subsolo, Bairro Liberdade, São Paulo, SP CEP:01504-001, Brazil

Full list of author information is available at the end of the article
}

fiber types (low proportion of oxidative fibers and high proportion of glycolytic fibers) $[4,5]$, changes in the bioenergetics (decrease of aerobic capacity, predominance of glycolytic metabolism and rapid accumulation of lactate) [6] and reduction of the capillary density and capillary/fiber ratio $[7,8]$. These alterations, alone or combined, are responsible for early muscle fatigue in COPD patients.

Since peripheral muscle dysfunction is one of the most serious systemic effects of COPD, strategies for improving muscle function are a priority in scientific research. In this context, phototherapy is an electrophysical intervention to be considered to prevent or postpone muscle

\section{Biomed Central}


fatigue in COPD due its effects, such as vasodilation, recruitment of collateral circulation, increased supply of oxygen and mitochondrial ATP level in the muscle [9].

Phototherapy by low-intensity laser and light-emitting diodes (LED) is a non-thermal therapy [10] characterized by a coherent and non-coherent beam of light, respectively [11]. It has been shown that both the laser and LED therapy produce similar effects due to the absorption of photons by chromophores in their tissue specific wavelengths. Currently, the LED has been presented as an alternative to the therapies that use low-intensity laser due to its low cost and smaller size [12].

The effects of phototherapy promoted by LED are mediated by the phenomenon of biostimulation [13]. In brief words, biostimulation can be explained by the absorption of energy by the intracellular chromophores [14]. The light energy is converted into chemical energy affecting positively several cellular biochemical processes $[10,14]$.

Skeletal muscle, a tissue with a high rate of aerobic metabolism, is highly responsive to the stimulating effects of phototherapy through infrared and red rays [15]. Among the acute effects of the LED, the prevention of muscular fatigue [16] and reduced levels of lactate [17] stand out. Additionally, improvement in exercise performance and attenuation of inflammatory biochemical markers (creatine kinase, $\mathrm{CK}$ ) and $\mathrm{C}$-reactive protein (CRP) [18] have been observed. In this context, this study will investigate whether the positive effects, previously demonstrated in healthy individuals and athletes, might occur in patients with COPD. Our hypothesis is that the therapeutic effects of LED as vasodilation, improves the collateral circulation, increasing the level of oxygen content in tissues, and increased levels of mitochondrial ATP [19] could minimize muscle fatigue, increasing exercise tolerance in patients with COPD.

The primary aim of this study is to investigate the acute effects of LED phototherapy on muscle function, exercise capacity and cardiorespiratory responses during isometric ( $60 \%$ of maximum voluntary contraction) and dynamic (maximal incremental cycle ergometer test) exercises in patients with COPD. The secondary goal is to assess the effects of LED phototherapy on biochemical markers (CK, CRP and lactic acid).

\section{Methods/Design \\ Study design}

This study is a crossover, double blind (patient and evaluator) and randomized trial. Randomization will be performed to determine whether the patient will receive LED or placebo (Figure 1). This study will be conducted in the Exercise Physiology Laboratory at the Nove de Julho University. This study was approved by the Ethics Committee of our institution (11/451953) and registered in Clinical Trials.gov NCT01448564 (2011-OCT-06).

The study will assess 35 patients with moderate to severe obstruction (forced expiratory volume-one second $\left(\mathrm{FEV}_{1}\right) \leq 70 \%$ predicted) and stable disease suggested by the absence of any change in medication and symptoms (increasing cough, increasing sputum volume and worsening sputum purulence) in the four weeks before the study. The exclusion criteria are oxygen-dependent patients, patients with orthopedic or neuromuscular disorders, and dark-skinned patients. Dark-skinned patients
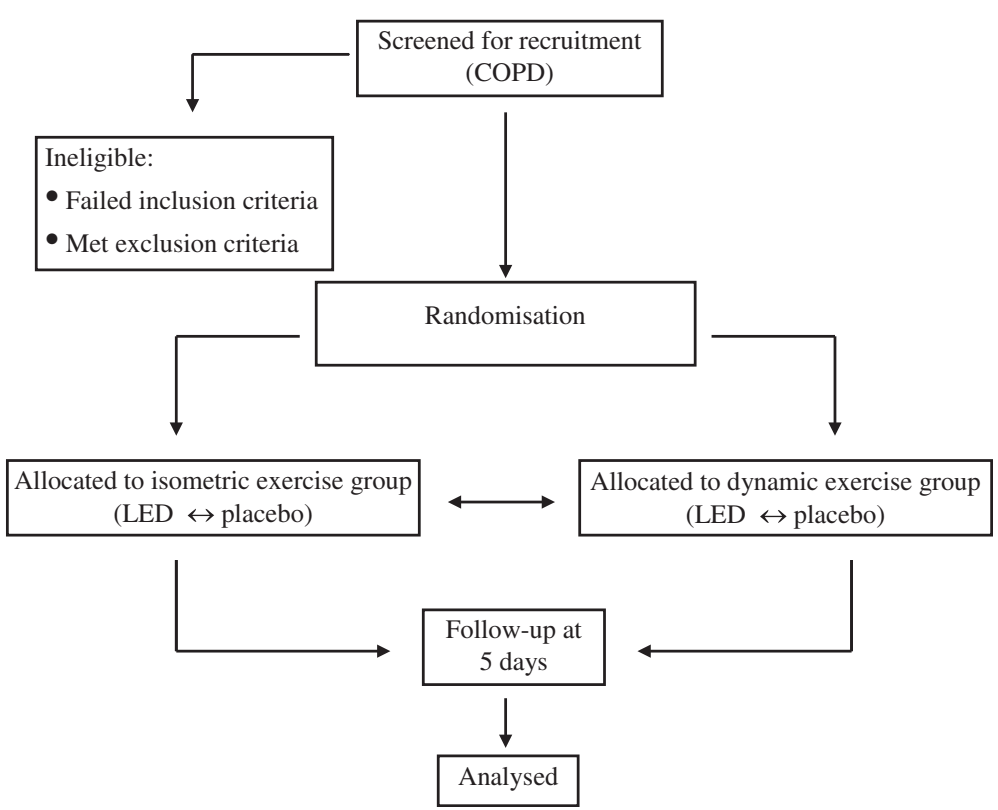

Figure 1 Flow of patients through the study. 
will be excluded because their greater epidermal melanin content acts as competing chromophores. This protocol was approved by the institutional ethics committee and all patients will sign a written informed consent before their participation in the study.

\section{Outcome measures}

The primary outcome for muscle function will be the endurance time (sec) on cycling. The secondary outcomes will be the slope coefficient from the regression line between the median frequency and endurance time, fatigue and dyspnea scores (from 0 to 10), and the levels of CK $(\mathrm{U} / \mathrm{L}), \mathrm{CRP}(\mathrm{mg} / \mathrm{dl})$ and lactate $(\mathrm{mmol} / \mathrm{L})$. In addition, for the dynamic protocol, the maximum workload (watts), $\mathrm{VO}_{2}$ peak (L), ventilation (L), and heart rate (bpm) variables will also be analyzed.

\section{Assessment}

\section{Spirometry}

Spirometry will be used to classify the severity of the obstruction and it will be performed at each visit before the tests to ensure similar pulmonary function on the different days. The tests will be performed using the CPF-System (Medical Graphics Corporation ${ }^{\circ}$, St. Paul, $\mathrm{MN}$, USA) after administering a bronchodilator (400 $\mu \mathrm{g}$ of inhaled salbutamol). The technical procedures, acceptability and reproducibility criteria will follow the recommendations of the Brazilian spirometry consensus [20]. Values of forced vital capacity and forced expiratory volume in the first secondwill be compared with those predicted for the Brazilian population. The following variables were recorded: $\mathrm{FVC}, \mathrm{FEV}_{1}, \mathrm{FEV}_{1} / \mathrm{FVC}$. The data were expressed in absolute values (liters) and in percentage of predicted (\%) No, the correct sentence is like that (percentage of predict)[21]. This test will take approximately 20 minutes.

\section{Skeletal muscle function assessment}

The strength of the quadriceps femoris will be obtained from the dominant leg by the maximal isometric voluntary contraction (MIVC). This measurement will be made with the patients seated on a leg extension chair (Carci ${ }^{\oplus}$, São Paulo, Brazil) at $60^{\circ}$ of knee flexion. A nonelastic strap connecting the ankle to a load cell (EMG System EMG800C, São José dos Campos, Brazil) will be interfaced to a computer to record the MIVC. The force will be expressed in Kgf. A strap will be placed across the patient's pelvis to minimize hip movement during the tests. The patients will perform three repetitions of MIVC of the knee extensors, each one maintained for five seconds, with a one minute rest between them. The highest value from the three reproducible contractions ( $<5 \%$ variability among attempts) will be considered for analysis, when the difference in strength of three contractions exceeds 5\%, another measure of MIVC will be requested. The greatest value of these three contractions will be considered as the MIVC [22]. After a resting period of five minutes, the IET of the quadriceps femoris will be evaluated by the isometric endurance time at $60 \%$ of the MIVC until the limit of tolerance (Tlim). The isometric endurance test will be finished when a $20 \%$ drop of the produced force occurs. All measurements will be performed with visual feedback on the computer screen [22]. Dyspnea and leg fatigue will be evaluated before and immediately after the test by the modified Borg scale [23]. This test will take approximately 15 minutes.

\section{Surface electromyography recording}

Surface electromyography (sEMG) signals will be recorded (EMG System, model EMG800C, Sao José dos Campos, Brazil) during the MIVC, isometric endurance test, and the incremental cycle ergometer test. The sEMG signals will be recorded with a preamplifier (gain 1,000x) and common mode rejection of more than $-85 \mathrm{~dB}$. The participants' skin will be prepared before the placement of the EMG electrodes by shaving the hair at the site of the electrode placement and cleaning the skin with alcohol [24].

Bipolar passive disposable dual $\mathrm{Ag} / \mathrm{AgCl}$ snap electrodes with a 1-cm diameter for each circular conductive area and a 2-cm center-to-center spacing will be placed over the longitudinal axes of the vastuslateralis. They will be placed in the direction of the muscle fiber, taking as reference two-thirds of the distance between the anterior superior iliac spine and the lateral edge of the patella [24]. Finally, a ground electrode will be put on the left elbow.

The sampling frequency will be $2,000 \mathrm{~Hz}[25]$ and the criterion adopted to normalize the EMG data will be the MIVC. The digitized EMG data will first be band-pass filtered at 20 to $400 \mathrm{~Hz}$ using a fourth order Butterworth filter with a zero lag. For the temporal analysis, the amplitude of the EMG signals will be expressed as root mean square (RMS) (1-s moving window) and normalized by MIVC [26]. For the time-frequency analysis, the EMG data will be analyzed with a short-time Fourier transform applied to 1-s epochs [27]. The median frequency of the spectrum for each epoch will be computed, and the linear regression of the median frequencies versus time will be determined. The slope of the straight line (indicating the rate of frequency change per second) will be adopted as a second index of fatigue [28-30]. All data were analyzed using a customized program written in Matlab (Mathworks Inc., Torrance, California, EUA).

\section{Cardiopulmonary exercise testing}

The maximal incremental cycle ergometer test will be carried out on an electromagnetically braked cycle 
ergometer (Corival, LODE B.V. Medical Technology, Groningen, The Netherlands) with gas exchange and ventilatory variables being analyzed breath-by-breath (Medical Graphics Corporation (MGC), St. Paul, MN, USA). After 2 minutes at rest and more than 2 minutes with a real "zero" workload obtained by a system that moves the ergometer flywheel, the power (W) will be continuously increased in a linear "ramp" pattern (5 to $15 \mathrm{~W} \mathrm{~min}^{-1}$ ) so that the incremental exercise test duration will be between 8 and 12 minutes [29]. The following data will be obtained breath-by-breath: pulmonary oxygen uptake $\left(\mathrm{VO}_{2}, \mathrm{~mL} \mathrm{~min}^{-1}\right)$, pulmonary carbon dioxide production $\left(\mathrm{VCO}_{2}, \mathrm{~mL} \mathrm{~min}^{-1}\right)$, minute ventilation $\left(\mathrm{VE}, \mathrm{L} \mathrm{min}^{-1}\right)$, tidal volume $(\mathrm{VT}, \mathrm{mL})$, respiratory rate (f, respirations per minute); ventilatory equivalent for $\mathrm{O}_{2}$ and $\mathrm{CO}_{2}\left(\mathrm{VE} / \mathrm{VO}_{2}\right.$ and $\mathrm{VE} / \mathrm{VCO}_{2}$, respectively), and end tidal partial pressures of $\mathrm{O}_{2}$ and $\mathrm{CO}_{2}\left(\mathrm{PETO}_{2}\right.$ and $\left.\mathrm{PETCO}_{2}, \mathrm{mmHg}\right)$. ECG tracings and heart rate (HR) will be recorded continuously and oxygen pulse $\left(\mathrm{VO}_{2} / \mathrm{HR}\right)$ will be calculated. Arterial oxygen saturation $\left(\mathrm{SpO}_{2}\right)$ will be measured by pulse oximetry. Blood pressure (BP) will be measured during every two minutes of exercise. The average $\mathrm{VO}_{2}$ for the last $15 \mathrm{~s}$ of the ramp will be considered representative of the subject's peak $\mathrm{VO}_{2}$. Subjects will be asked to rate dyspnea and leg fatigue at exercise cessation by using the modified Borg scale [23]. This test will take approximately 30 minutes.

\section{Dynamic endurance testing}

For the dynamic endurance test (DET), the same procedures described above will be followed, except with 75\% of the maximal workload obtained from incremental cycle ergometer test used instead of the IET. Patients will perform this test until the limit of tolerance (Tlim).

\section{Venous blood}

Blood samples will be collected to measure the lactate levels, as well as the activity of CK and CRP. To measure these settings, a qualified nurse (blind to the group allocation) will perform the asepsis of ventral side of the arm. A blood sample will be collected prior to the application of the LED or placebo and immediately after ending the isometric endurance testing (Visits 1 and 2). The same procedure will be performed at Visits 3 and 4 prior to the application of the LED or placebo and after the cycle ergometer testing. The samples will be analyzed with infrared spectrophotometry via a spectrophotometer $\left(\mathrm{FEMTO}^{\circ}\right.$ Industry and Trade of Instruments, São Paulo, SP, Brazil) and specific kits for blood lactate analysis (Bioclin', Belo Horizonte, Brazil) and CK analysis (Labtest ${ }^{\circ}$, Lagoa Santa, Brazil). PCR analysis will be carried out by the agglutination method using a specific analysis kit (Wiener Laboratories ${ }^{\bullet}$, Rosario, Argentina).

\section{LED}

Patients will receive a single application of LED or placebo on different days (a week apart). The LED or placebo will be administered immediately before the isometric and dynamic protocols. The radiation will be held stationary with slight pressure of the LED cluster (THOR Photomedicine $e^{\circ}$ London, UK) in contact with skin at an angle of $90^{\circ}$. The application will be performed on two points along the ventral side of the rectus femoris [31], one point on the greater prominence of the muscle belly of the vastuslateralis and vastusmedialis muscles. For the isometric exercise protocol, the application will be performed only on the right quadriceps femoris, while for the dynamic exercise protocol, both lower limbs will receive the application on the four sites for the quadriceps femoris, two sites for the hamstring muscle belly, and one site in the center of the triceps surae [18]. Each point will be irradiated for $30 \mathrm{~s}$. The energy received at each point will be $41.7 \mathrm{~J}$. The irradiation settings are summarized in Table 1.

For the placebo, the same procedures will be performed but without irradiation. During the application of the LED or placebo, the patient will use protective glasses that make it impossible to see whether there is light being irradiated. This test will take approximately five minutes.

\section{Protocol}

In the first visit, patients undergo spirometry, maximum voluntary isometric contraction (MIVC) and incremental cycle ergometer test, one hour apart. The isometric and dynamic endurance will be conducted in two visits each, totaling four visits (a week apart) with the subjects

\section{Table 1 Settings for LED cluster}

\begin{tabular}{|c|c|}
\hline Number of LEDs & 69 (34 red LEDs and 35 infrared LEDs) \\
\hline Wavelength & $660 \mathrm{~nm}$ (red) and $850 \mathrm{~nm}$ (infrared) \\
\hline Frequency & Continuous output \\
\hline Optical output & $10 \mathrm{~mW}$ (red) and $30 \mathrm{~mW}$ (infrared) \\
\hline LED spot size & $0.2 \mathrm{~cm}^{2}$ (for both), total spot sizes $13.8 \mathrm{~cm}^{2}$ \\
\hline Power density & $0.05 \mathrm{~W} \mathrm{~cm}^{-2}$ (red) and $0.15 \mathrm{~W} \mathrm{~cm}^{-2}$ (infrared) \\
\hline Energy & $\begin{array}{l}41.7 \mathrm{~J}(0.3 \mathrm{~J} \text { from each red LED and } 0.9 \mathrm{~J} \\
\text { from each infrared LED) }\end{array}$ \\
\hline Energy density & $1.5 \mathrm{~J} \mathrm{~cm}^{-2}$ (red) and $4.5 \mathrm{~J} \mathrm{~cm}^{-2}$ (infrared) \\
\hline Treatment time & $\begin{array}{c}30 \mathrm{~s} \text { per point, } 120 \mathrm{~s} \text { (total treatment time for } \\
\text { isometric test), } 420 \mathrm{~s} \text { (total treatment time for } \\
\text { dynamic test) }\end{array}$ \\
\hline $\begin{array}{l}\text { Number of irradiation } \\
\text { points per muscle }\end{array}$ & $\begin{array}{l}4 \text { points (isometric test) and } 14 \text { points } \\
\text { (dynamic test) }\end{array}$ \\
\hline Total energy delivered & $166.8 \mathrm{~J}$ (isometric test), $583.8 \mathrm{~J}$ (dynamic test) \\
\hline Application mode & $\begin{array}{c}\text { Cluster held stationary to skin with slight } \\
\text { pressure at a } 90^{\circ} \text { angle }\end{array}$ \\
\hline
\end{tabular}


alternating between being in the test group and control group.

First, a venous blood sample will be taken from the patients. The isometric endurance test (IET) will be performed with $60 \%$ of MIVC. Then, patients will be randomized to receive either a placebo or LED application. Immediately after finishing this procedure, the patients will carry out the IET until the limit of tolerance or a fall of $20 \%$ strength is observed. After the test, another blood sample will be taken. During the next visit (one week later), the same order of procedures will be performed, except with the opposite application (LED or placebo) that was applied at Visits 2 and3.

For the dynamic endurance test (DET), the same procedures described above will be followed, except with $75 \%$ of the maximal workload obtained from incremental cycle ergometer test used instead of the IET. A summary of the protocol can be visualized in Figure 2.

\section{Statistical analysis}

The sample size was calculated based on the primary outcome, that is, endurance time. Assuming a Type 1 error rate of 0.05 and a Type 2 error rate of 0.2 , with a magnitude difference of $55 \mathrm{sec}$ at the dynamic endurance testing, a standard deviation of $79 \mathrm{sec}$ [32], and a hypothetical drop-out rate of $10 \%, 35$ patients with COPD would be needed to show statistically significant

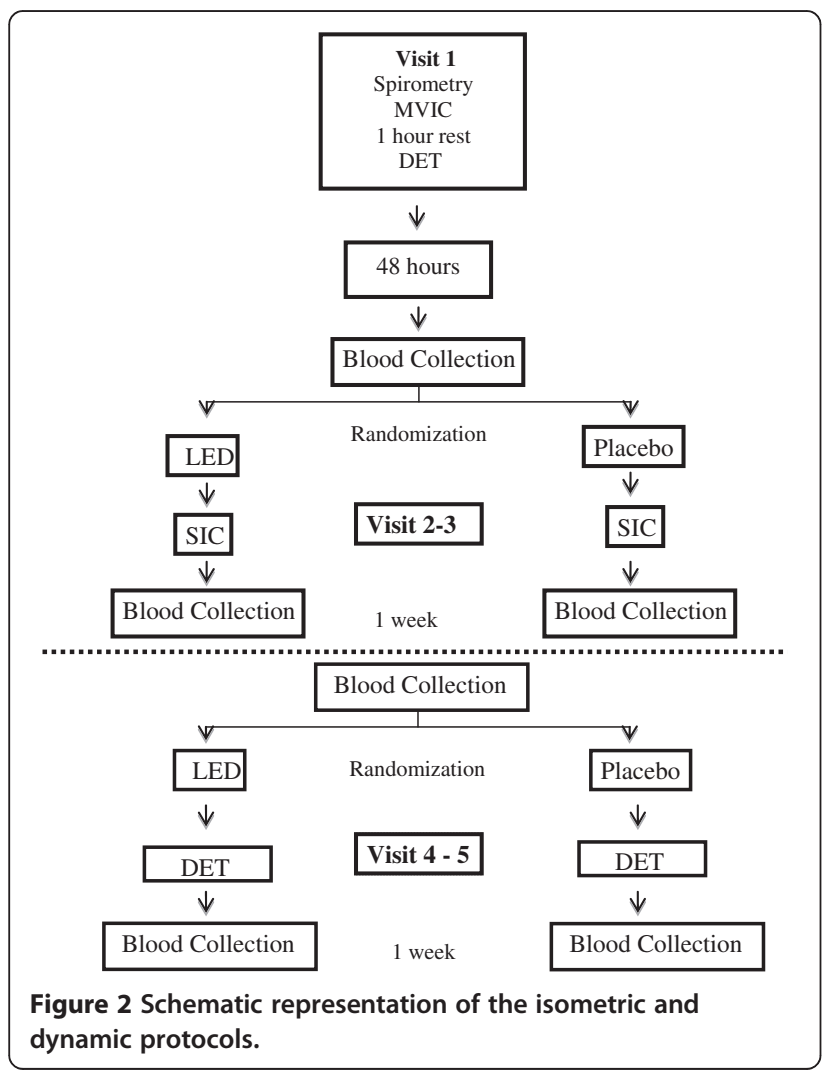

differences between LED and placebo in the endurance time. It will be used as the intention to treat analysis with the baseline data being used for missing data from patients who did not complete the whole protocol [33]. An additional analysis of the results involving only those patients who complete the treatment originally allocated will also be performed (per protocol analysis).

The normal distribution of data will be verified by the Kolmogorov-Smirnov test. The parametric data will be expressed by mean and standard deviation. The nonparametric data will be expressed by median and interquartile range. Differences in the variables of muscle function, exercise capacity and cardiorespiratory responses between the LED and placebo treatments will be compared with the paired Student's $t$-test. Changes in median frequency and root mean square will be analyzed by repeated measures analysis of variance (basal, 25\%, $50 \%, 75 \%$ and $100 \%$ of the endurance time) [34].

The linear regression analysis of the median frequency versus endurance time will be performed to obtain the slope coefficient of the straight line. For the correlations between the electromyographic variables (median frequency and root mean square) with endurance time, peak workload at cycling, and biochemical markers (CK, CRP and lactate). Pearson's correlation will be used for normal distributions and Spearman's correlation will be used for non-normal distributions. We used the GraphPad Software, Inc., GraphPadInStat ${ }^{\mathrm{tm}}($ version 2.0) La Jolla, CA, USAto calculate the sample size.

\section{Discussion}

Patients with COPD are susceptible to contractile fatigue [35]due to poor muscle endurance [35], reduced muscular capillarization [36] and early onset of lactic acidosis during exercise [37].

It is well known that fatigue and muscle injuries often occur after high intensity exercise and are accompanied by an inflammatory response. In this context, Leal Júnioret al. [38] showed that phototherapy can delay the onset of fatigue, probably by local mechanisms, including minimizing oxidative stress. Studies have shown that infrared laser application before high-intensity exercise can increase the removal of blood lactate and reduce muscle damage, providing a faster muscle recovery $[39,40]$.

The reasons for the increased blood lactate removal and reduced muscular injuries after laser therapy are still uncertain. A possible explanation is that the effects of laser therapy occur by transforming light energy into chemistry and propagating their effects to the tissues and surrounding areas. The absorbed energy can act in two ways: (i) stimulating the release of autacoid substances (histamine, serotonin and bradykinin) and (ii) modifying the normal enzymatic reactions, both in the sense of excitement as inhibition [41]. 
Another possible mechanism behind the therapeutic effects of laser therapy is the interaction of irradiated photons with specific receptors in the mitochondria causing an increase in mitochondrial function, along with an increase in ATP (adenosine triphosphate), ribonucleic acid (RNA) and protein synthesis. This interaction leads to an increase in oxygen consumption and also in the ATP synthesis. Consequently, the phototherapy increases the cellular metabolism and, thus, decreases the inflammatory process and lactate production [11]. When absorbed by the tissues, the phototherapy can cause changes in muscle activity because of changes in the ion gradient [42], the concentration of ATP [43] and activity of $\mathrm{Na}^{+} \mathrm{K}^{+}$-ATPase [44].

Muscle fatigue results in the inability to maintain the metabolic process of muscle contraction. This can occur due to reduced mitochondrial energy supply to the muscle fibers. The explanation for the ability of the phototherapy to decrease muscle fatigue is that it promotes arteriolar vasodilation and improves peripheral microcirculation [45]; consequently, there is an increased supply of oxygen to muscle tissues.

The decrease in activity of the enzyme creatine kinase (CK) after phototherapy could be related to a protective effect of the phototherapy in the development of muscle ischemia. There are some indications that the phototherapy can reduce reactive oxygen species (ROS), while antioxidant levels increase [46]. Moreover, as mentioned earlier, laser therapy can stimulate the respiratory chain and the synthesis of ATP [41]. These effects, in turn, also contribute to a decrease in CK activity and the reduction of blood lactate accumulation leading to recovery from muscle fatigue [32,46-50]. Based on previous studies, phototherapy can be considered as a novel and non-invasive treatment for reduction of muscle fatigue induced by exercise in patients with COPD.

\section{Trial status}

This study protocol is registered with ClinicalTrials.gov (NCT01448564) and this study is active, but is not yet open for participant recruitment.

\footnotetext{
Abbreviations

ATP: Adenosine triphosphate; BP: Blood pressure; Bpm: Beats per minute; CK: Creatine kinase; CRP: C-reactive protein; COPD: Chronic obstructive pulmonary disease; DET: Dynamic endurance test; FEV $_{1}$ : Forced expiratory volume in 1 second; FVC: Forced vital capacity; FEV 1 /FVC: Ratio of FEV 1 to FVC; HR: Heart rate; IET: Isometric endurance test; LED: Light-emitting diodes; MIVC: Maximal isometric voluntary contraction; $\mathrm{PETCO}_{2}$ : End tidal partial pressure of $\mathrm{CO}_{2} ;$ PETO$_{2}$ : End tidal partial pressure of $\mathrm{O}_{2}$; RMS: Root mean square; RNA: Ribonucleic acid; ROS: Reactive oxygen species; sEMG: Surface electromyography; $\mathrm{SIC}$ : Submaximal isometric contraction; $\mathrm{SpO}_{2}$ : Arterial oxygen saturation; Tlim: Limit of tolerance; $\mathrm{VCO}_{2}$ : Pulmonary carbon dioxide production; VE: Minute ventilation; $\mathrm{VO}_{2}$ : Pulmonary oxygen uptake; VT: Tidal volume.
}

\section{Competing interests}

The authors declare that they have no competing interests.

\section{Authors' contributions}

EFM and SDC designed the trial protocol and drafted the manuscript. ECPLJ and PHM contributed to the manuscript. All authors read and approved the final manuscript.

\section{Acknowledgements}

EFM is supported by São Paulo Research Foundation (FAPESP/SP)

\section{Author details}

${ }^{1}$ Post Graduate Program in Rehabilitation Sciences, Nove de Julho University, São Paulo, Brazil. ${ }^{2}$ Post Graduate Program in Biophotonics Applied to Health Sciences, Nove de Julho University, São Paulo, Brazil. ${ }^{3}$ Methodist University of Piracicaba, Rod. Luís Ometto, KM 24, Distrito Industrial Santa Bárbara D Oeste, CEP:13451-900, São Paulo, SP, Brazil. ${ }^{4}$ Rua Vergueiro 235/249 2 subsolo, Bairro Liberdade, São Paulo, SP CEP:01504-001, Brazil.

Received: 25 July 2012 Accepted: 19 April 2013

Published: 10 May 2013

\section{References}

1. Berton E, Antonucci R, Palange P: Skeletal muscle dysfunction in chronic obstructive pulmonary disease. Monaldi Arch Chest Dis 2001, 56:418-422.

2. Gosselink R, Troosters T, Decramer M: Peripheral muscle weakness contributes to exercise limitation in COPD. Am J Respir Crit Care Med 1996, 153:976-980.

3. Serres I, Gautier V, Varray A, Préfaut C: Impaired skeletal muscle endurance related to physical inactivity and altered lung function in COPD patients. Chest 1998, 113:900-905.

4. Gosker HR, Engelen MP, van Mameren H, van Dijk PJ, van der Vusse GJ, Wouters EF, Schols AM: Muscle fiber type IIX atrophy is involved in the loss of fat-free mass in chronic obstructive pulmonary disease. Am J Clin Nutr 2002, 76:113-119.

5. Gosker HR, van Mameren H, van Dijk PJ, Engelen MP, van der Vusse GJ, Wouters EF, Schols AM: Skeletal muscle fibre-type shifting and metabolic profile in patients with chronic obstructive pulmonary disease. Eur Respir J 2002, 19:617-625.

6. Maltais F, LeBlanc P, Whittom F, Simard C, Marquis K, Bélanger M, Breton MJ, Jobin J: Oxidative enzyme activities of the vastuslateralis muscle and the functional status in patients with COPD. Thorax 2000, 55:848-853.

7. Jobin J, Maltais F, Doyon JF, LeBlanc P, Simard PM, Simard AA, Simard C: Chronic obstructive pulmonary disease: capillarity and fiber characteristics of skeletal muscle. J Cardiopulm Rehabil 1998, 18:432-437.

8. Whittom F, Jobin J, Simard PM, Leblanc P, Simard C, Bernard S, Belleau R, Maltais F: Histochemical and morphological characteristics of the vastuslateralis muscle in patients with chronic obstructive pulmonary disease. Med Sci Sports Exerc 1998, 30:1467-74

9. Karu T: Photobiological fundamentals of low-power laser therapy. IEEE J Quant Electron 2002, 23:1703-1717.

10. Lin F, Josephs SF, Alexandrescu DT, Ramos F, Bogin V, Gammill V, Dasanu CA, De Necochea-Champion R, Patel AN, Carrier E, Koos DR: Lasers, stem cells, and COPD. J Transl Med 2010, 8:16.

11. Huang YY, Chen AC, Carroll JD, Hamblin MR: Biphasic dose response in low level light therapy. Dose-response 2009, 7:358-383.

12. Enwemeka CS: Light is light. Photomed. Laser Surg 2005, 23:159-160.

13. Mester E, Szende B, Tota JG: Effect of laser on hair growth of mice. Kiserl Orvostud 1967, 19:628-631.

14. Karu Tl: Primary and secondary mechanisms of action of visible-to-near IR radiation on cells. J Photochem Photobiol 1999, 49:1-17.

15. Hayworth CR, Rojas JC, Padilla E, Holmes GM, Sheridan EC, Gonzalez-Lima F: In vivo low-level light therapy increases cytochrome oxidase in skeletal muscle. Photochem Photobiol 2010, 86:673-680.

16. Ferraresi C, Hamblin MR, Parizotto NA: Low-level laser (light) therapy (LLLT) on muscle tissue: performance, fatigue and repair benefited by the power of light. Photonics Lasers Med 2012, 1:267-286.

17. De Marchi T, Leal Junior EC, Bortoli C, Tomazoni SS, Lopes-Martins RA, Salvador M: Low-level laser therapy (LLLT) in human progressive-intensity running: effects on exercise performance, skeletal muscle status, and oxidative stress. Lasers Med Sci 2012, 27:231-236.

18. Baroni BM, Leal Junior EC, Geremia JM, Diefenthaeler F, Vaz MA: Effect of light-emitting diodes therapy (LEDT) on knee extensor muscle fatigue. Photomed Laser Surg 2010, 28:653-658. 
19. Oron U, llic S, De Taboada L, Streeter J: Ga-As $(808 \mathrm{~nm})$ laser irradiation enhances ATP production in human neuronal cells in culture. Photomed Laser Surg 2007, 25:180-182.

20. Sociedade Brasileira de Pneumologia e Tisiologia: Diretrizes para testes de função pulmonar. [Guidelines for pulmonary function tests]. J Pneumol 2002, 28(Suppl 3):S44-S58.

21. Pereira CAC, Barreto SP, Simões JG: Valores de referência para espirometria em uma amostra da população brasileira adulta. [Reference values for spirometry in a sample of the adult Brazilian population]. J Pneumol 1992, 18:10-22.

22. Mathur S, Eng JJ, MacIntyre DL: Realiability of surface EMG during sustained contractions of quadríceps. J Electromyogr Kinesiol 2005, 15:102-110.

23. Borg G: Psychophysical scaling with applications in physical work and the perception of exertion. Scand J Work Environ Health 1990, 16(Suppl 1):55-58.

24. Hermens HJ, Freriks B, Disselhorst-Klug C, Rau G: Development of recommendations for SEMG sensors and sensor placement procedures. J Eletromyogr Kinesiol 2000, 10:361-374.

25. Alkner BA, Tesch PA, Berg HE: Quadriceps EMG/force relationship in knee extension and leg press. Med Sci Sports Exerc 2000, 32:459-463.

26. Burden A, Bartlett R: Normalisation of EMG amplitude: an evaluation and comparison of old and newmethods. Med Eng Phys 1999, 21:247-257.

27. De Luca CJ: The use of surface electromyography in biomechanics. J App/ Biomech 1997, 13:135-163.

28. Madeleine P, Farina D, Merletti R, Arendt-Nielsen L: Upper trapezius muscle mechanomyographic and electromyographic activity in humans during low force fatiguing and non-fatiguing contractions. Eur J Appl Physiol 2002, 87:327-336.

29. Merletti R, Lo Conte L, Cisari C, Actis MV: Age related changes in surface myoelectric signals. Scand J Rehabil Med 1992, 24:25-36.

30. Merletti R, Farina D, Gazzoni M, Schieroni MP: Effect of age on muscle functions investigated with surface electromyography. Muscle Nerve 2002, 25:65-76.

31. Buchfuhrer MJ, Hansen JE, Robinson TE, Sue DY, Wasserman K, Whipp BJ: Optimizing the exercise protocol for cardiopulmonary assessment. J Appl Physiol 1983, 55:1558-1564.

32. Leal Junior EC, Lopes-Martins RA, Baroni BM, De Marchi T, Rossi RP, Grosselli D, Generosi RA, de Godoi V, Basso M, Mancalossi JL, Bjordal JM: Comparison between single-diode low-level laser therapy (LLLT) and LED multi-diode (cluster) therapy (LEDT) applications before highintensity exercise. Photomed Laser Surg 2009, 27:617-623.

33. Moher D, Hopewell S, Schulz KF, Montori V, Gøtzsche PC, Devereaux PJ, Elbourne D, Egger M, Altman DG: CONSORT 2010 explanation and elaboration: updated guidelines for reporting parallel group randomised trials. BMJ 2010, 340:c869.

34. Nápolis LM, Dal Corso S, Neder JA, Malaguti C, Gimenes AC, Nery LE. Neuromuscular electrical stimulation improves exercise tolerance in chronic obstructive pulmonary disease patients with better preserved fat-free mass. Clinics 2011, 66:401-406.

35. Man WD, Soliman MG, Gearing J, Radford SG, Rafferty GF, Gray BJ, Polkey Ml, Moxham J: Symptoms and quadriceps fatigability after walking and cycling in chronic obstructive pulmonary disease. Am J Respir Crit Care Med 2003, 168:562-567.

36. Coronell C, Orozco-Levi M, Méndez R, Ramírez-Sarmiento A, Gáldiz JB, Gea J: Relevance of assessing quadriceps endurance in patients with COPD. Eur Respir J 2004, 24:129-136.

37. de Almeida P, Lopes-Martins RA, De Marchi T, Tomazoni SS, Albertini R Corrêa JC, Rossi RP, Machado GP, da Silva DP, Bjordal JM, Leal Junior EC: Red $(660 \mathrm{~nm})$ and infrared $(830 \mathrm{~nm})$ low-level laser therapy in skeletal muscle fatigue in humans: what is better? Lasers Med Sci 2012, 27:453-8.

38. Leal Junior EC, Lopes-Martins RA, Dalan F, Ferrari M, Sbabo FM, Generosi RA, Baroni BM, Penna SC, Iversen W, Bjordal JM: Effect of 655-nm low level laser therapy on exercise-induced skeletal muscle fatigue in humans. Photomed Laser Surg 2008, 26:419-424.

39. Leal Junior EC, Lopes-Martins RA, Vanin AA, Baroni BM, Grosselli D, De Marchi T, Iversen W, Bjordal JM: Effect of $830 \mathrm{~nm}$ low-level laser therapy in exercise-induced skeletal muscle fatigue in humans. Lasers Med Sci 2009, 24:425-431.

40. Vacca RA, Marra E, Passarella S, Petragallo VA, Greco M: Increase in cytosolic and mitochondrial protein synthesis in rat hepatocytes irradiated in vitro by He-Ne laser. J Photochem Photobiol B 1996, 34:197-202.
41. Gulsoy M, Ozer GH, Bozkulak O, Tabakoglu HO, Aktas E, Deniz G, Ertan C: The biological effects of 632.8-nm low energy He-Ne laser on peripheral blood mononuclear cells in vitro. J Photochem Photobiol B 2005, 82:199-202.

42. Leal Junior EC, Lopes-Martins RA, Baroni BM, De Marchi T, Taufer D, Manfro DS, Rech M, Danna V, Grosselli D, Generosi RA, Marcos RL, Ramos L, Bjordal JM: Effect of $830 \mathrm{~nm}$ low-level laser therapy applied before highintensity exercises on skeletal muscle recovery in athletes. Lasers Med Sci 2009, 24:857-863.

43. Low J, Laserterapia RA: Eletroterapia explicada principios e prática. [Laser Therapy. In Electrotherapy Explained Principles and Practice]. 3rd edition. Edited by Rosa VLD, Bardeli N. São Paulo: Manole Editor LTDA; 2001:389-409.

44. Ihsan FR: Low level laser therapy accelerates collateral circulation and enhances microcirculation. Photomed Laser Surg 2005, 23:289-294.

45. Rizzi CF, Mauriz JL, Freitas Correa DS, Moreira AJ, Zettler CG, Filippin LI, Marroni NP, Gonzalez-Gallego J: Effects of low-level laser therapy (LLLT) on the nuclear factor (NF)-kappaB signaling pathway in traumatized muscle. Lasers Surg Med 2006, 38:704-713.

46. Leal Junior EC, Lopes-Martins RA, Rossi RP, De Marchi T, Baroni BM, de Godoi V, Marcos RL, Ramos L, Bjordal JM: Effect of cluster multi-diode light emitting diode therapy (LEDT) on exercise-induced skeletal muscle fatigue and skeletal muscle recovery in humans. Lasers Surg Med 2009, 41:572-577.

47. Leal Junior EC, Lopes-Martins RA, Frigo L, De Marchi T, Rossi RP, de Godoi V, Tomazoni SS, Silva DP, Basso M, Filho PL, de Valls CF, Iversen W, Bjordal JM: Effects of low-level laser therapy (LLLT) in the development of exerciseinduced skeletal muscle fatigue and changes in biochemical markers related to postexercise recovery. J Orthop Sports PhysTher 2010, 40:524-532.

48. Schulte E, Kallenberg LA, Christensen H, Disselhorst-Klug C, Hermes HJ, Rau G, Søgaard K: Comparison of the eletromyographic activity in the upper trapezius and biceps brachii muscle in subjects with muscular disorders: a pilot study. Eur J Appl Physiol 2006, 96:185-193.

49. Karu TI, Afanasyeva NI, Kolyakov SF, Pyatibrat LV, Welser L: Changes in absorbance of monolayer of living cells induced by laser irradiation at 633, 670 and $820 \mathrm{~nm}$. Quantum Elect 2001, 7:982-988.

50. Silveira PC, Silva LA, Fraga DB, Freitas TP, Streck EL, Pinho R: Evaluation of mitochondrial respiratory chain activity in muscle healing by low-level laser therapy. J Photochem Photobiol B 2009, 95:89-92.

doi:10.1186/1745-6215-14-134

Cite this article as: Miranda et al:: Effects of light-emitting diodes on muscle fatigue and exercise tolerance in patients with COPD: study protocol for a randomized controlled trial. Trials 2013 14:134.

\section{Submit your next manuscript to BioMed Central and take full advantage of:}

- Convenient online submission

- Thorough peer review

- No space constraints or color figure charges

- Immediate publication on acceptance

- Inclusion in PubMed, CAS, Scopus and Google Scholar

- Research which is freely available for redistribution 